\title{
Response to Commentary by W. Jost on: Pharmaceutical, Biological, and Clinical Properties of Botulinum Neurotoxin Type A Products
}

\author{
Jürgen Frevert ${ }^{1}$
}

Published online: 8 April 2015

(c) The Author(s) 2015. This article is published with open access at Springerlink.com

Differences in manufacturing processes can affect the properties of biological products. This is especially true for products based on botulinum toxin. The manufacturing process for $\mathrm{Xeomin}^{\circledR} /$ Bocouture $^{\circledR}$ (NT 201, incobotulinumtoxinA, INCO) employs chromatographic methods and produces a pure neurotoxin without any other bacterial contaminants such as the so-called complexing proteins or clostridial DNA. In contrast, Botox ${ }^{\circledR} /$ Vistabel $^{\circledR}$ (onabotulinumtoxin, ONA) is produced with precipitation techniques resulting in a complex composed of several proteins.

As Dr. Jost [1] points out, a comparison of the potencies of the preparations based merely on different bioassays is not sufficient. The active ingredient in all botulinum toxin products is of course the neurotoxin, but in the absence of international standards for the activity of BoNTA products, each manufacturer employs its own proprietary biological assay for testing potency units, which in principle differ from company to company and might provide different results. Neither a mouse lethal dose (LD50 assay) nor molecular effect in a cellular assay correctly reflects the therapeutic situation (e.g., on a dystonic muscle). As stated in the article, these assays also depend on the testing conditions; for example, the composition of the diluent, which is critical for the low concentration of the neurotoxin. The SNAP 25 cleavage assay only measures one part of the activity of the neurotoxin.

To determine any differences in potency, the products have to be compared in clinical head-to-head studies.

\footnotetext{
Jürgen Frevert

juergen.frevert@merz.de

1 Merz Pharmaceuticals GmbH, Potsdam, Germany
}

Perhaps the most scientifically valid studies to date are two which were conducted in patients with blepharospasm and cervical dystonia [2,3]. These were large, rigorous, double-blind, randomized, non-inferiority trials, in which participants had a stable therapeutic response on ONA before study start with maintenance of the same dose regimen during the trial. Both showed that INCO, when administered at the same doses as prior successful ONA treatment, was noninferior in clinical efficacy to ONA. In a subsequent review article summarizing results from studies in focal dystonia, Dr. Jost states: "This approach...indicated that equal units of NT 201 have a comparable safety and efficacy profile to BOT and both phase III studies supported the dose ratio of 1:1" [4].

In aesthetic medicine, the most rigorous study to date is that of Sattler et al. [5]. This randomized 381 patients in a $3: 1$ ratio to receive $24 \mathrm{U}$ of INCO or ONA for the treatment of glabellar frown lines. There was no difference in initial activity and the authors of the paper concluded that both treatments were equally effective over at least 12 weeks. It is therefore surprising that in his commentary Dr. Jost makes reference to a study by Moers-Carpi et al. [6], in which different doses of ONA and INCO were compared in the treatment of glabellar lines. The study purported to show that $20 \mathrm{U}$ of ONA was as effective as $30 \mathrm{U}$ of INCO in reducing the severity of glabellar lines 28 days postinjection, but was flawed in that it did not include an arm comparing 30 U ONA with 20 U INCO. When Prager and Rappl [7] published a similar study with the missing arm (20 U INCO and $30 \mathrm{U}$ ONA), the clinical effect was the same despite the $50 \%$ difference in dose. Taken together, both studies result in a conversion ratio of 1:1 for ONA versus INCO, again confirming the conclusion from the registration studies. 
The author agrees that for aesthetic indications the incidence of neutralizing antibodies against botulinum neurotoxin is low, partly because the relatively low doses used minimize the potential for their formation. However, the composition of the products is important. The immune system requires a signal to become activated against an antigen. Some of the complexing proteins present in ONA and $\mathrm{ABO}$ are hemagglutinins, which bind to immune cells leading to their activation. Dr. Jost is correct in stating that all evidence demonstrating the immune-stimulating effect of complexing proteins is currently based on preclinical studies. Furthermore, all statements concerning clinical differences are retrospective, and no head-to-head clinical studies have analyzed differences in the immunological potential of the different botulinum toxin products. However, after almost 10 years on the market and around 1 million treated patients, no antibody production has been observed in treatment-naïve patients receiving INCO. It therefore seems justified to draw the conclusion that removal of the superfluous proteins reduces the risk of neutralizing antibody formation and the potential for subsequent treatment failure. Considering that patients treated with ONA or $\mathrm{ABO}$ require a shortened injection interval to prevent the reoccurrence of symptoms before the usually applied 12-week injection intervals, the use of INCO has been shown to be tolerable and efficacious [8].

What does all this mean for the practicing physician? If a product with less biological activity were administered for therapeutic indications at unit doses based on a more potent product, patients may not experience adequate reduction in symptoms. For aesthetic indications, the results may not meet patient expectations, which could lead to dissatisfaction. With INCO this is clearly not the case and switching from an established effective dose of ONA to the same number of labeled units of INCO can be expected to provide a similar clinical result.

Given the differences in manufacturing processes between ONA and INCO, and the presence (ONA) or absence of complexing proteins (INCO), the products are definitely not identical. Are they similar in terms of treatment outcome for the same indications at the same unit dose? Yes.
The usage of either of the different BoNT products should always follow the instructions of the respective approved product label.

Conflict of interest J. Frevert is employee of Merz Pharmaceuticals $\mathrm{GmbH}$.

Open Access This article is distributed under the terms of the Creative Commons Attribution-NonCommercial 4.0 International License (http://creativecommons.org/licenses/by-nc/4.0/), which permits any noncommercial use, distribution, and reproduction in any medium, provided you give appropriate credit to the original author(s) and the source, provide a link to the Creative Commons license, and indicate if changes were made.

\section{References}

1. Jost WH. 'Similar To' is not 'Identical With', and 'Identical With' is not 'The Same As'. Drugs R D. 2015;15:11-2.

2. Benecke R, Jost WH, Kanovsky P, Ruzicka E, Comes G, Grafe S. A new botulinum toxin type A free of complexing proteins for treatment of cervical dystonia. Neurology. 2005;64(11):1949-51.

3. Roggenkämper P, Jost WH, Bihari K, Comes G, Grafe S, NT 201 Blepharospasm Study Team. Efficacy and safety of a new botulinum toxin type A free of complexing proteins in the treatment of blepharospasm. J Neural Transm. 2006;113(3):303-12.

4. Jost WH, Blümel J, Grafe S. Botulinum neurotoxin type A free of complexing proteins (XEOMIN) in focal dystonia. Drugs. 2007;67(5):669-83.

5. Sattler G, Callander MJ, Grablowitz D, et al. Noninferiority of 557 incobotulinumtoxinA, free from complexing proteins, compared 558 with another botulinum toxin type A in the treatment of glabellar 559 frown lines. Dermatol Surg. 2010;36(Suppl 4):2146-54.

6. Moers-Carpi M, Dirschka T, Feller-Heppt G, Hilton S, Hoffmann K, Philipp-Dormston WG, Rütter A, Tan K, Chapman MA, Fulford-Smith A. A randomised, double-blind comparison of 20 units of onabotulinumtoxinA with 30 units of incobotulinumtoxinA for glabellar lines. J Cosmet Laser Ther. 2012;14(6):296-303.

7. Prager W, Rappl T. Phase IV study comparing incobotulinumtoxin A and onabotulinumtoxinA using a 1:1.5 dose-conversion ratio for the treatment of glabellar frown lines. Cosmet Dermatol. 2012;11(4):267-71.

8. Evidente VG, Truong D, Jankovic J, Comella CL, Grafe S, Hanschmann J. IncobotulinumtoxinA $\left(\mathrm{Xeomin}^{\circledR}\right)$ injected for blepharospasm or cervical dystonia according to patient needs is well tolerated. Neurol Sci. 2014;346(1-2):116-20. 